\title{
Molecular diversity and growth features of Flavobacterium columnare strains isolated in Finland
}

\author{
L.-R. Suomalainen ${ }^{1, *}$, H. Kunttu ${ }^{1}$, E. T. Valtonen ${ }^{1}$, V. Hirvelä-Koski ${ }^{2}$, M. Tiirola ${ }^{1}$ \\ ${ }^{1}$ Department of Biological and Environmental Science, PO Box 35, 40014 University of Jyväskylä, Finland \\ ${ }^{2}$ National Veterinary and Food Research Institute, Oulu regional unit, PO Box 517, 90101 Oulu, Finland
}

\begin{abstract}
Columnaris disease caused by Flavobacterium columnare is a problem in fish farming worldwide. During the last $15 \mathrm{yr}$, outbreaks have started to emerge in Finland. Flavobacterium columnare Type Strain NCIMB $2248^{\mathrm{T}}$ and 30 Finnish F. columnare isolates were studied using analysis of 16S rDNA by restriction-fragment length polymorphism (16S RFLP), length heterogeneity analysis of polymerase chain reaction (LH-PCR) products, automated ribosomal intergenic spacer analysis (ARISA), and 16S rDNA sequence analysis. All isolates fell into RFLP Genomovar I and had the same length in the LH-PCR analysis. Based on ARISA, 8 genetically different strains were selected for further analyses. The growth of these strains under different temperatures, $\mathrm{NaCl}$ concentrations, and $\mathrm{pH}$ values was tested. The Finnish F. columnare strains did not grow at $\mathrm{NaCl}$ concentrations $>0.1 \%$ or at $\mathrm{pH}$ values $\leq 6.5$, and they were susceptible to several antimicrobial agents, but not to Polymyxin B or neomycin. These findings may aid in development of methods for disease management at fish farms.
\end{abstract}

KEY WORDS: Flavobacterium columnare · ARISA · RFLP · 16S rRNA gene sequencing

\section{INTRODUCTION}

Flavobacterium columnare, the causative agent of columnaris disease, is a bacterial fish pathogen that was first described in 1922 (Davis 1922). The bacterium causes skin and gill infections in farmed freshwater fishes worldwide. Columnaris outbreaks started to emerge in Finland in the early 1990s (Koski et al. 1993) and have increased annually to become a serious threat to the fish farming industry (Suomalainen 2005). The causative bacterium has previously been known as Bacillus columnaris, Chondrococcus columnaris, Cytophaga columnaris, and Flexibacter columnaris, but this taxonomical confusion was resolved in 1996 when Bernardet et al. (1996) transferred the bacterium to the genus Flavobacterium. Currently, F. columnare is considered a phenotypically homogenous species when compared to other species in the Flavobacterium/Flexibacter/Cytophaga group (Song et al. 1988,
Bernardet et al. 1996, Shamsudin \& Plumb 1996, Bader \& Shotts 1998a).

Several studies of the genetic variability of Flavobacterium columnare strains using 16S rDNA restriction fragment analyses (16S RFLP) have shown the division of the strains into 3 16S RFLP genomovars (Triyanto \& Wakabayashi 1999, Triyanto et al. 1999, Michel et al. 2002). Recently, intergenic spacer region (ISR) sequencing (Arias et al. 2004), amplified fragment-length polymorphism (AFLP) fingerprinting (Figueiredo et al. 2005), and analysis by randomly amplified polymorphic DNA (RAPD) (Thomas-Jinu \& Goodwin 2004) have been applied to F. columnare isolates. However, these studies have not covered Finnish F. columnare strains; indeed, the only European isolates studied have been from France. Moreover, previous studies have not characterized basic growth features or antibiotic susceptibilities of genetically different $F$. columnare types to indicate alterna- 
tives for the prevention and treatment of the disease. The use of oxytetracycline is the only method practically applied for the treatment of columnaris disease in Finland, so there is a real threat of development of resistant strains. Therefore, physiological testing and genetic typing of $F$. columnare isolates is of great importance for understanding the increasing severity of outbreaks and for designing disease management strategies. Tolerance to salinity is of special interest, since columnaris disease has not been reported from coastal areasof Finland, where the salinity of the brackish water is between 2 and $7 \%$. However, F. columnare Type Strain NCIMB $2248^{\mathrm{T}}$ (National Collection of Industrial, Marine, and Food Bacteria) is known to grow in media with $0.5 \%$ $\mathrm{NaCl}$ (Bernardet \& Grimont 1989).

In the present study, we investigated 30 Finnish Flavobacterium columnare isolates obtained from disease outbreaks in northern and central Finland, in order to select representative strains for further analysis. The molecular diversity of these strains was studied using 16S rDNA RFLP, LH-PCR (length heterogeneity analysis of polymerase chain reaction products, Suzuki et al. 1998), and ARISA (automated ribosomal intergenic spacer analysis, Fisher \& Triplett 1999). Using this information, 8 genetically different strains were selected for the physiological analysis. The growth patterns of 8 selected strains were studied under different temperatures, salt concentrations, and $\mathrm{pH}$, as well as the susceptibility of the strains to various antibiotics, to gather information for developing potential disease management strategies.

\section{MATERIALS AND METHODS}

Bacterial strains and DNA extraction. Thirty Flavobacterium columnare strains isolated from disease outbreaks at Finnish fish farms from 1993 to 2003 were obtained for this study (Table 1). The strains were stored frozen at $-70^{\circ} \mathrm{C}$ in enriched AO-broth (Bernardet \& Keroault 1989) supplemented with $10 \%$ glycerol and $10 \%$ bovine serum. For DNA extraction and growth measurements, the strains were grown in AO-broth for $24 \mathrm{~h}$ with constant agitation $(120 \mathrm{rpm})$. For extraction of DNA, the cells were lysed with Proteinase $\mathrm{K}$, and the DNA was purified by phenol-chloroform-isoamyl alcohol extractions and precipitated with $\mathrm{NaCl}$ and isopropanol, as described previously (Tiirola et al. 2003).

LH-PCR and ARISA. The partial 16S rRNA gene was amplified using the universal bacterial primers fD1 with ird700 label and Prun518 (Table 2), yielding a PCR product of $517 \mathrm{bp}$. The reaction mixture contained $0.3 \mathrm{mM}$ dNTPs, $0.3 \mu \mathrm{M}$ of each primer, $1 \times$ DynaZyme buffer, and 2 U DynaZyme II DNA-polymerase (Finnzymes, Espoo, Finland). The total reaction volume in each PCR tube was $40 \mu \mathrm{l}$, with $1 \mu \mathrm{l}$ of template DNA (20 to $50 \mathrm{ng}$ ). The PCR included an initial denaturation step at $95^{\circ} \mathrm{C}$ for $5 \mathrm{~min}, 30$ cycles of amplification $\left(94^{\circ} \mathrm{C}\right.$ for $30 \mathrm{~s}, 55^{\circ} \mathrm{C}$ for $60 \mathrm{~s}, 72^{\circ} \mathrm{C}$ for $180 \mathrm{~s}$ ), and a final extension step at $72^{\circ} \mathrm{C}$ for $15 \mathrm{~min}$. For ARISA, the univer-

Table 1. Flavobacterium columnare. Strains used in this study. Information regarding the year of isolation, fish farm, and fish species is given for each isolate. ${ }^{*}$ Strains studied for their $16 \mathrm{~S}$ rDNA sequence, growth characteristics, and antibiotic susceptibility

\begin{tabular}{|c|c|c|c|c|}
\hline $\begin{array}{l}\text { Isolate/ } \\
\text { strain code }\end{array}$ & $\begin{array}{l}\text { Fish } \\
\text { farm }\end{array}$ & $\begin{array}{l}\text { Fish } \\
\text { species }\end{array}$ & Watercourse & $\begin{array}{l}\text { ARISA } \\
\text { group }\end{array}$ \\
\hline NCIMB $2248^{\mathrm{T}}$ & & Chinook salmon & Washington, USA & $\mathrm{F}^{*}$ \\
\hline $3294 / 95$ & $1^{\mathrm{a}}$ & Trout & River Oulujoki & $\mathrm{A}^{*}$ \\
\hline $10819 / 96$ & $1^{\mathrm{a}}$ & Arctic charr & River Oulujoki & A \\
\hline $8128 / 97$ & $1^{\mathrm{a}}$ & Arctic charr & River Oulujoki & $\mathrm{B}^{*}$ \\
\hline $3147 / 98$ & $1^{\mathrm{a}}$ & Trout & River Oulujoki & A \\
\hline $1277 / 99$ & $1^{\mathrm{a}}$ & Trout & River Oulujoki & $\mathrm{A}$ \\
\hline $1179 / 01$ & $1^{\mathrm{a}}$ & Brown trout & River Oulujoki & $\mathrm{A}$ \\
\hline $2390 / 02$ & $1^{\mathrm{a}}$ & Salmon & River Oulujoki & $\mathrm{A}$ \\
\hline $8239 / 97$ & $2^{\mathrm{a}}$ & Rainbow trout & River Iijoki & $\mathrm{C}^{*}$ \\
\hline $9528 / 97$ & $3^{\mathrm{a}}$ & Rainbow trout & River Torniojoki & $\mathrm{C}$ \\
\hline $1991 / 94$ & $4^{\mathrm{a}}$ & Rainbow trout & River Oulujoki & $\mathrm{A}$ \\
\hline $1468 / 99$ & $5^{\mathrm{a}}$ & Brook trout & River Oulujoki & $\mathrm{A}$ \\
\hline 1199/00 & $6^{\mathrm{a}}$ & Rainbow trout & River Kymijoki & A \\
\hline $1397 / 00$ & $7^{\mathrm{a}}$ & Rainbow trout & River Oulujoki & $\mathrm{D}^{*}$ \\
\hline $1820 / 02$ & $8^{a}$ & Rainbow trout & River Vienan Kemijoki & A \\
\hline $2287 / 02$ & $9^{a}$ & Trout & River Lestijoki & $\mathrm{A}$ \\
\hline $2559 / 93$ & $10^{\mathrm{a}}$ & Salmon & River Simojoki & A \\
\hline $\mathrm{Ke} / 02$ & $11^{\mathrm{b}}$ & Salmon & River Kemijoki & $E^{*}$ \\
\hline Mo/02 & $12^{\mathrm{b}}$ & Salmon & River Oulujoki & $\mathrm{A}$ \\
\hline $\mathrm{Ke} / 03$ & $13^{\mathrm{b}}$ & Salmon & River Kemijoki & $\mathrm{C}$ \\
\hline Os/03 & $14^{\mathrm{b}}$ & Salmon & River Kemijoki & $\mathrm{G}^{*}$ \\
\hline $\mathrm{Ra} / 03$ & $15^{\mathrm{b}}$ & Salmon & River Iijoki & $\mathrm{E}$ \\
\hline Htan4/03 & $16^{\mathrm{c}}$ & Rainbow trout & River Kymijoki & $\mathrm{A}$ \\
\hline Htan5/03 & $16^{\mathrm{c}}$ & Rainbow trout & River Kymijoki & $\mathrm{H}^{*}$ \\
\hline Htan6/03 & $16^{\mathrm{c}}$ & Rainbow trout & River Kymijoki & $\mathrm{H}$ \\
\hline $\mathrm{Mo} / 03$ & $17^{\mathrm{c}}$ & Trout & River Oulujoki & $\mathrm{E}$ \\
\hline Htku1/03 & $16^{\mathrm{c}}$ & Pikeperch & River Kymijoki & $\mathrm{H}$ \\
\hline Htku2/03 & $16^{\mathrm{c}}$ & Pikeperch & River Kymijoki & $\mathrm{E}$ \\
\hline Lauh/03 & $18^{\mathrm{c}}$ & Grayling & River Kymijoki & $\mathrm{A}$ \\
\hline BA1972/03 & $19^{\mathrm{a}}$ & Rainbow trout & River Oulujoki & $\mathrm{A}$ \\
\hline FK2/03 & $11^{\mathrm{b}}$ & Salmon & River Kemijoki & $\mathrm{E}$ \\
\hline
\end{tabular}


Table 2. Flavobacterium columnare. Primers for the polymerase chain reaction used in genetic analysis of Finnish isolates

\begin{tabular}{|llll|}
\hline Primer & Direction & Sequence & Source \\
\hline fD1 & Forward & 5'-AGA GTT TGA TCC TGG CTC AG-3' $^{\prime}$ & Weisburg et al. (1991) \\
rD1f & Forward & $5^{\prime}$-GGC TGG ATC ACC TCC TT-3' & Weisburg et al. (1991) \\
23Sr & Reverse & $5^{\prime}$-GGG TTB CCC CAT TCR G-3' & Borneman \& Triplet (1997) \\
Prun518 & Reverse & $5^{\prime}$-ATT ACC GCG GCT GCT GG-3' & Muyzer et al. (1993) \\
Com2Ph & Forward & 5'-AAA CTC AAA GGA ATT GAC GG-3' & Schwieger \& Tebbe (1998) \\
FvpF1 & Forward & 5'-GCC CAG AGA AAT TTG GAT-3' & Bader et al. (2003) \\
FvpR1 & Reverse & 5'-TGC GAT TAC TAG CGA ATC C-3' & Bader et al. (2003) \\
\hline
\end{tabular}

sal primers rD1forward and 23Sr (with ird700 label) were used (Table 2), amplifying a fragment of approximately $700 \mathrm{bp}$. The reaction mixture was as described above. PCR included an initial denaturation step at $94{ }^{\circ} \mathrm{C}$ for $2 \mathrm{~min}, 35$ cycles of amplification $\left(94^{\circ} \mathrm{C}\right.$ for $30 \mathrm{~s}, 52^{\circ} \mathrm{C}$ for $30 \mathrm{~s}, 72^{\circ} \mathrm{C}$ for $30 \mathrm{~s}$ ), and final elongation for $15 \mathrm{~min}$. The LH-PCR and ARISA were performed with a LI-COR 4200 automatic sequencer (LI-COR BioTech) in a $6 \%$ Long Ranger denaturating polyacrylamide gel (FMC Bioproducts). Quantity One software (Bio-Rad Laboratories) was used for analyzing the fragment-length data.

16S rDNA restriction analysis. The $16 \mathrm{~S}$ rRNA gene of Flavobacterium columnare was amplified with the primers fD1 and rD1. Then, $10 \mu \mathrm{l}$ of PCR product was digested with the restriction enzymes MspI and HaeIII (MBI Fermentas). The digested samples were electrophoresed in a $12 \%$ native polyacrylamide gel electrophoresis system (Sambrook et al. 1989), followed by ethidium-bromide staining and UV-illumination.

Cloning and sequence analysis. Nearly full length 16S rDNA of 7 selected strains representing different ARISA genotypes were sequenced in 3 overlapping segments. The gene was amplified with 3 primer sets (primers fD1/Prun518, same protocol as in LH-PCR; Table 2). For primer pairs FvpF1/FvpR1 and Com2Ph/ FvpR1 (Table 2), PCR amplification included an initial denaturation step at $94^{\circ} \mathrm{C}$ for $10 \mathrm{~min}, 30$ cycles of amplification $\left(95^{\circ} \mathrm{C}\right.$ for $30 \mathrm{~s}, 59^{\circ} \mathrm{C}$ for $30 \mathrm{~s}, 72^{\circ} \mathrm{C}$ for $60 \mathrm{~s}$ ), and the final extension step at $72^{\circ} \mathrm{C}$ for $6 \mathrm{~min}$. The PCR products were cloned into TA-vector pGEMT-easy (Promega) and electroporated into Escherichia coli JM109 cells. Plasmids were extracted with a Sigma GenElute kit and sequenced bidirectionally with irdlabelled primers with Excel SequiTherm Kit II (Epicentre Technologies) using a LI-COR 4200 sequencer. The 16S rDNA sequences obtained from the Flavobacterium columnare strains were submitted to the EMBL (European Molecular Biology Laboratory) database under Accession Numbers AJ831824 to AJ831830. The sequences were analyzed using AlignIR software (LI-COR). Phylogenetic trees were created by a neighbor-joining method using Clustal X software.
Alignment positions with gaps were not included in the calculations. The topology of the tree was evaluated by the bootstrap resampling method with 1000 replicates.

Growth analysis. The growth of selected Flavobacterium columnare strains and the type strain was tested at different temperatures, $\mathrm{pH}$ values, and salt concentrations. The strains were first cultivated in $10 \mathrm{ml}$ of AO-broth ( $\mathrm{pH} 7.0)$ at $22^{\circ} \mathrm{C}$, with constant agitation (150 rpm) until the culture reached $50 \%$ saturation (50\% of the maximum optical density value measured at $595 \mathrm{~nm}$ wavelength). The effect of temperature on the growth rate was studied at 17.0, 19.0, 22.0, 25.0, and $27.4^{\circ} \mathrm{C}$ by adding $5 \mu \mathrm{l}$ of bacterial culture to $250 \mu \mathrm{l}$ of AO-broth on a microtiter plate. The effect of salt and $\mathrm{pH}$ was studied similarly at $22^{\circ} \mathrm{C}$, but the AO-broth was supplemented with $0,0.01,0.02,0.04,0.06,0.08$, and $0.1 \%$ of $\mathrm{NaCl}$ or adjusted to $\mathrm{pH} 6.2,6.5,6.8,7.4,8.0,8.6$, and 9.2 (pH adjusted with $\mathrm{HCl}$ and $\mathrm{NaOH}$ ), respectively. Triplicate samples were analyzed in all the experiments. The measurements of optical density at $595 \mathrm{~nm}$ were continued until cultures reached 30 to $50 \%$ of saturation. Differences in the growth of Finnish strains were analyzed using SPSS 11.0 software and non-parametric Kruskal-Wallis tests.

Antibiotic susceptibility tests. Susceptibility of selected Finnish Flavobacterium columnare strains and the Type Strain NCIMB $2248^{\mathrm{T}}$ to antimicrobial agents was tested as described by Michel et al. (2002) using AO agar. The diameters of the inhibition zones were measured after $2 \mathrm{~d}$ at $21 \pm 1{ }^{\circ} \mathrm{C}$. The strains were divided into 3 categories: susceptible (S), intermediate (I), or resistant (R) (NCCLS 1999). Ampicillin ( $\geq 17 \mathrm{~mm}$ / 14-16 mm/13 mm), erythromycin (23/14-22/12), gentamycin (15/13-14/12), nitrofurantoi (17/1516/14), neomycin (17/13-16/12), Polymyxin B (12/911/8), streptomycin (15/12-14/11), tetracycline (19/15-18/10), trimethoprim-sulpha (16/11-15/10), and florfenicol (24/21-23/20) were tested (breakpoints of S/I/R for each antibiotic given in parentheses). Commercial discs of Oxoid were used, except for florfenicol, for which Neo-Sensitabs were used (A/S Rosco). 


\section{RESULTS}

All Flavobacterium columnare strains yielded a 517 bp PCR product in the LH-PCR analysis. Eight different ARISA profiles were observed, 3 of which (A, $B$, and D) were closely similar (Fig. 1). Even though it was not known if the differing bands in Groups B and D were amplified from the ISR region, these extra bands were used to group the isolates and select the strains for further studies, because the same amplification profiles were detected when the PCR was repeated. In the $16 \mathrm{~S}$ rDNA digestion analysis, no differences between strains were detected. The Type Strain NCIMB $2248^{\mathrm{T}}$ had a restriction profile similar to all the Finnish isolates in both digestions (not shown). This 16S RFLP digestion profile corresponded to Genomovar I in the classification created by Triyanto \& Wakabayashi (1999). In the 16S rDNA sequencing, a 1329 bp continuous sequence was assembled from a representative of each ARISA group (marked with asterisks in Table 1). In the neighbor-joining tree, the Finnish F. columnare strains (Sequences AJ831824 to AJ831830) constituted a separate, highly homologous group, differing from strains isolated from other parts of the world (Fig. 2), but clustering with the sequence obtained from the EMBL (European Molecular Biology

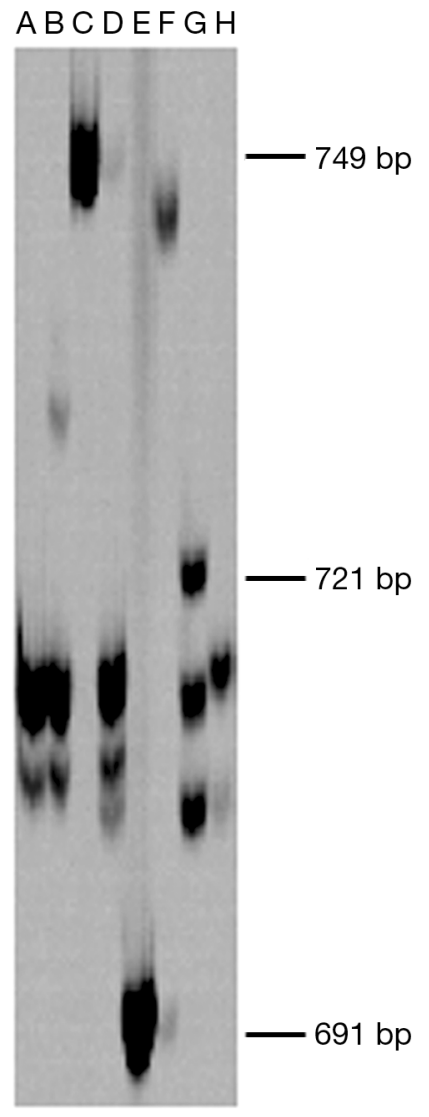

Fig. 1. Flavobacterium $\mathrm{Co}-$ lumnare. Automated ribosomal intergenic spacer analysis (ARISA) patterns (ARISA Groups A to $\mathrm{H}$ ) of the Finnish $F$. columnare isolates and $F$. columnare NCIMB $2248^{\mathrm{T}}$ (corresponding strain codes are given in Table 1), with a calculatory DNA ladder
Laboratory) database as $F$. columnare Strain IFO

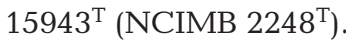

Temperature, salinity, and $\mathrm{pH}$ had significant effects on the growth of Finnish Flavobacterium columnare strains (Kruskal-Wallis test, $\chi^{2}=72.7, \mathrm{df}=4, \mathrm{p}=0.000$ for temperature; $\chi^{2}=68.9, \mathrm{df}=4, \mathrm{p}=0.000$ for $\mathrm{pH}_{\text {; }}$ and $\chi^{2}=74.7, \mathrm{df}=6, \mathrm{p}=0.000$ for salinity) (Fig. 3). The Finnish strains were able to grow at $\mathrm{pH}$ values from 6.8 to 9.2 , but growth was greatly inhibited at $\mathrm{pH} 6.2$ to 6.5 (Fig. 3B). Growth decreased as salt concentration increased (Fig. 3C), and only the Group A strain showed any growth at a salt concentration of $0.1 \%$. However, neither $0.1 \%$ salt concentration nor $\mathrm{pH} 6.5$ inhibited the growth of the Type Strain NCIMB $2248^{\mathrm{T}}$. Differences in growth between strains were detected at different temperatures (Kruskal-Wallis test, $\chi^{2}=$ 21.4, $\mathrm{df}=6, \mathrm{p}<0.01$ ) and salinities (Kruskal-Wallis test, $\left.\chi^{2}=17.3, \mathrm{df}=6, \mathrm{p}<0.05\right)$.

The 8 selected Flavobacterium columnare strains were sensitive to all antimicrobial agents tested, except neomycin and Polymyxin B. Neomycin showed ISR Category I in the case of ARISA Group A, E, G, and H strains. For Polymyxin B, ARISA Group A showed Category I and Group C, E, G, and H strains were resistant.

\section{DISCUSSION}

The 16S rRNA gene is widely used in phylogenetic analysis and in typing bacterial strains due to its highly conserved nature. The ISR between the $16 \mathrm{~S}$ and 23S rRNA changes more rapidly (Leblond-Bourget et al. 1996), and can be used for genotypic analysis at the intraspecies level. ARISA has, indeed, been shown to be a useful typing method for bacterial identification based on the observation that considerable length heterogeneity is apparent when the $16 \mathrm{~S}$ to $23 \mathrm{~S}$ rDNA spacer region is amplified from strains carrying multiple rRNA operons (Gurtler \& Stanisich 1996). In the present study we used ARISA classification to identify genetically different strains for further analyses. We were able to expand the division of Finnish Flavobacterium columnare isolates, all belonging to Genomovar I, into 7 genetically different subgroups, as F. columnare NCIMB $2248^{\mathrm{T}}$ represented the 8th subgroup. In the study of Arias et al. (2004), sequence analysis of ISR detected 4 genomic groups belonging to Genomovars I and II among isolates from USA and Brazil. However, the number of different ISR sequences present in each group was not defined. If the presence of multiple sequences is not taken into consideration, phylogenetic analysis solely based on sequence data may give contradicting results, because it is not known which copy of the ISR gene is amplified. Recently Darwish \& Ismaiel (2005) designed a primer 
set for amplification of the ISR region, and RFLP analysis of the PCR product revealed a subdivision of Genomovars I and II into 2 groups each. Multiple ISR sequences do not hamper RFLP analyses or ARISA analyses, since the results are repeatable.

Most Finnish Flavobacterium columnare isolates fell into Group A in ARISA. Interestingly, the Strains Htku1/03, Htku2/03, Htan4/03, Htan5/03, and Htan6/03 (belonging to 3 subgroups in the ARISA division) were isolated from 1 disease outbreak. The presence of several genotypes in disease outbreaks has previously been documented for $F$. columnare by Triyanto et al. (1999) and for F. psychrophilum by Madetoja et al. (2001). The isolation of several genetic groups from the same outbreak in this paper was due to the improved cultivation method used in isolation (dilution cultivation) and a thorough screening of the isolates during the outbreak. We suggest that the coexistence of different genetic groups in the same infection is a common phenomenon in columnaris disease, because $F$. columnare is ubiquitous in aquatic environments (Rickard et al. 2003, Revetta et al. 2005). The phenomenon can contribute to the continuous nature of outbreaks during summer or to increased virulence (e.g. Gandon et al. 2001, Read \& Taylor 2001). Indeed, differences in virulence have been demonstrated in

ATCC43622 (FCRR16SB)

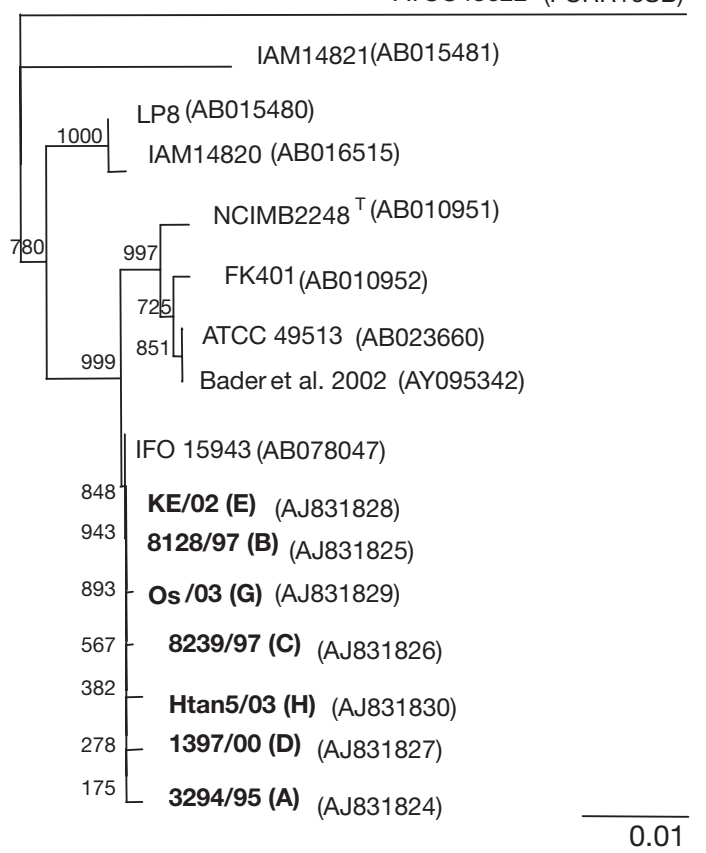

Fig. 2. Flavobacterium columnare. Phylogenetic tree based on neighbor-joining analysis of the $16 \mathrm{~S}$ rDNA sequence data obtained from the representatives of Finnish $F$. columnare ARISA Groups A to $\mathrm{H}$ (bold type) and other F. columnare sequences obtained from the European Molecular Biology Laboratory database (EMBL accession numbers given in parentheses)
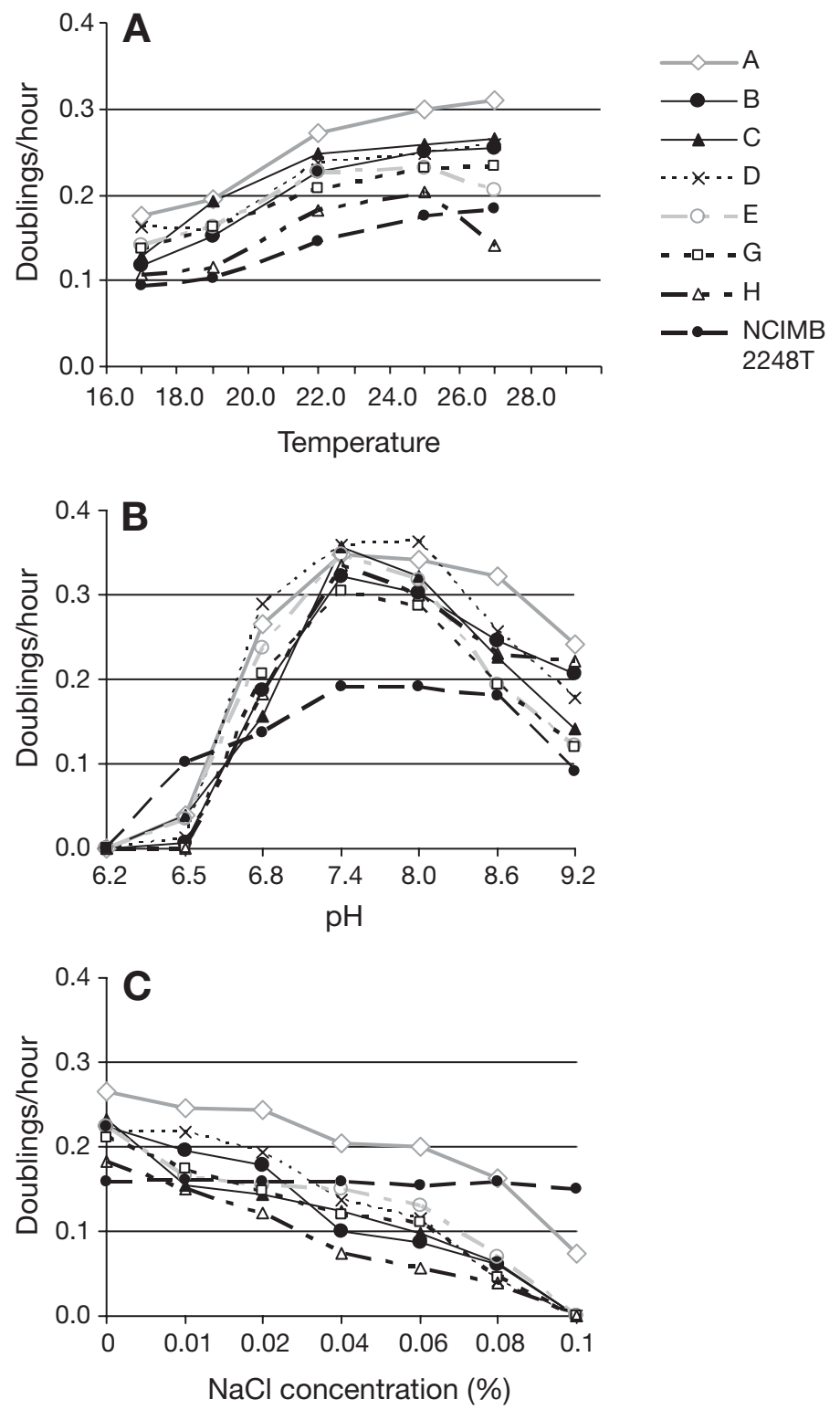

Fig. 3. Flavobacterium columnare. Maximum growth rates (doublings $\mathrm{h}^{-1}$ ) of 7 selected Finnish F. columnare isolates and the F. columnare Type Strain NCIMB $2248^{\mathrm{T}}$ (ARISA Groups A to $\mathrm{H}$, Table 1) under different (A) temperatures, (B) $\mathrm{pH}$ values, and $(\mathrm{C}) \mathrm{NaCl}$ concentrations. Corresponding strain codes are given in Table 1

F. columnare (Decostere et al. 1998). However, more detailed surveys of individual outbreaks should be made to obtain additional information on the characteristics of the disease, because the factors influencing the bacterial communities behind the outbreaks may be more complicated than has previously been thought.

Restriction analysis of the 16S rRNA gene yielded identical results from all the strains studied, including the type strain. Triyanto \& Wakabayashi (1999) used a 
similar 16S rDNA digestion analysis to Type 23 Flavobacterium columnare isolates from various areas. They found 3 different genomic groups within the species. When compared to their results, the Finnish isolates belonged to Genomic Group I, along with the Type Strain NCIMB $2248^{\mathrm{T}}$. According to classification based on 16S rDNA digestion analysis, all European F. columnare strains so far studied fall into Genomovar I (Triyanto \& Wakabayashi 1999, Michel et al. 2002). All the studied F. columnare strains also yielded a $517 \mathrm{bp}$ fragment in the LH-PCR analysis, showing that this length may be characteristic for the pathogen.

In the phylogenetic tree constructed from the sequence data, the Finnish strains fell into a distinct cluster, separate from the other Flavobacterium columnare strains except IFO $15943^{\mathrm{T}}$. This IFO $15943^{\mathrm{T}}$ sequence obtained from the EMBL database should, however, be identical to the NCIMB $2248^{\mathrm{T}}$ sequence, since it was derived from the same strain (Nakagawa et al. 2002). The difference between these 2 sequences is most likely due to sequencing errors. Recently, $F$. columnare Strain ATCC 43622 was identified and renamed as F. johnsoniae (Darwish et al. 2004). Because previous authors have used this strain in phylogenetic analyses (Toyama et al. 1996, Bader \& Shotts 1998a,b), we included it in our sequence analysis even though it represents a different species.

Growth of the Finnish Flavobacterium columnare strains was significantly influenced by temperature, increasing from $0.1-0.2$ to $0.2-0.3$ doublings $\mathrm{h}^{-1}$ when the temperature increased from 17 to $25^{\circ} \mathrm{C}$. Other studies have reported that some $F$. columnare strains can grow at temperatures $>30^{\circ} \mathrm{C}$, and even at $+37^{\circ} \mathrm{C}$ (Bernardet 1989, Decostere et al. 1998). Although the growth of the bacteria increases at elevated temperatures, this is not the only factor increasing fish mortality at high temperatures during columnaris infection. At higher temperatures the transmission of the pathogen and mortality caused by the disease are higher (Suomalainen et al. 2005a), and the adhesion of the pathogen in fish tissues has also been shown to increase at elevated temperatures (Decostere et al. 1999).

The Ministry of Agriculture and Forestry in Finland recommends tetracycline for treatment of columnaris disease, but the use of florfenicol is accepted as an alternative antibiotic if tetracycline-resistant strains should occur. Even though the Finnish Flavobacterium columnare strains seem to be sensitive to tetracycline at the moment, the development of resistance can happen. As seen in this study, several other antibiotics are efficient inhibitors of $F$. columnare growth. Due to the external nature of the infection (Bernardet 1997), salt or acidic bathing could have a potential in prevention and treatment of $F$. columnare infections in ecological disease management. Altinok \& Grizzle (2001) found that rearing fish in salinities between 3 and $9 \%$ inhibited F. columnare infection, and columnaris disease has not been reported to occur in seawater or in brackish water areas around Finland (salinity from 2 to $7 \%$ ), reflecting the poor growth ability evan at even low salt concentrations. However, despite the promising results in vitro, the success of acidic or salt bathing was shown to be limited during an experimental infection in another study (Suomalainen et al. 2005b). Therefore, antibiotic medication is still the most efficient method known for treatment of columnaris disease in Finnish aquaculture.

Acknowledgements. This work was supported by the University of Jyväskylä (Rector's grant for L.-R.S.), Academy of Finland (Project of Sustainable Use of Natural Resources, SUNARE), and the Graduate School of Biological Interactions, Turku, Finland. We thank Dr. P. Rintamäki-Kinnunen for kindly providing some of the isolates used in this study, and Prof. R. Jones and D. Benesh for their helpful comments on this article.

\section{LITERATURE CITED}

Altinok I, Grizzle JM (2001) Effects of low salinities on Flavobacterium columnare infection of euryhaline and freshwater stenohaline fish. J Fish Dis 24:361-367

Arias CR, Welker TL, Shoemaker CA, Abernathy JW, Klesius PH (2004) Genetic fingerprinting of Flavobacterium columnare isolates from cultured fish. J Appl Microbiol 97: 421-428

Bader JA, Shotts EBJ (1998a) Determination of phylogenetic relationships of Flavobacterium psychrophilum (Flexibacter psychrophilus), Flavobacterium columnare (Flexibacter columnaris) and Flexibacter maritimus by sequence analysis of $16 \mathrm{~S}$ ribosomal RNA genes amplified by polymerase chain reaction. J Aquat Anim Health 10:320-327

Bader JA, Shotts EBJ (1998b) Identification of Flavobacterium and Flexibacter species by species-specific polymerase chain reaction primers to the $16 \mathrm{~S}$ ribosomal RNA gene. J Aquat Anim Health 10:311-319

Bader JA, Shoemaker CA, Klesius PH (2003) Rapid detection of columnaris disease in channel catfish (Ictalurus punctatus) with a new species-specific 16-S rRNA gene-based primer for Flavobacterium columnare. J Microbiol Methods 52:209-220

Bernardet JF (1989) 'Flexibacter columnaris': first description in France and comparison with bacterial strains from other origins. Dis Aquat Org 6:37-44

Bernardet JF (1997) Immunization with bacterial antigens: Flavobacterium and Flexibacter infections. Dev Biol Stand 90:179-188

Bernardet JF, Grimont PAD (1989) Deoxyribonucleic acid relatedness and phenotypic characterization of Flexibacter columnaris sp. nov., nom. rev., Flexibacter pschrophilus sp. nov., nom. rev., and Flexibacter maritimus Wakabayashi, Hikida and Masumura 1996. Int J Syst Bacteriol 39:346-354

Bernardet JF, Keroault B (1989) Phenotypic and genomic studies of 'Cytophaga psychrophila' isolated from diseased rainbow trout (Oncorhynchus mykiss) in France. Appl Environ Microbiol 55:1796-1800

Bernardet JF, Segers P, Vancanneyt M, Berthe F, Kersters K, 
Vandamme P (1996) Cutting a Gordian knot: emended classification and description of the genus Flavobacterium, emended description of the family Flavobacteriaceae and proposal of Flavobacterium hydatis nom. nov. (Basonym, Cytophaga aquatilis Strohl and Tait 1978). Int J Syst Bacteriol 46:128-148

Borneman J, Triplet EW (1997) Molecular microbial diversity in soils from eastern Amazonia: evidence for unusual microorganisms and population shifts associated with deforestation. Appl Environ Microbiol 63:2647-2653

Darwish AM, Ismaiel AA (2005) Genetic diversity of Flavobacterium columnare examined by restriction fragment length polymorphism and sequencing of the $16 \mathrm{~S}$ ribosomal RNA gene and the 16S-23S rDNA spacer. Mol Cell Probes 19:267-274

Darwish AM, Ismaiel AA, Newton JC, Tang J (2004) Identification of Flavobacterium columnare by a species-specific polymerase chain reaction and renaming of ATCC43622 strain to Flavobacterium johnsoniae. Mol Cell Probes $1: 421-427$

Davis HS (1922) A new bacterial disease of fresh-water fishes. Bull US Bur Fish 38:261-280

Decostere A, Haesebrouck F, Devriese LA (1998) Characterization of four Flavobacterium columnare (Flexibacter columnaris) strains isolated from tropical fish. Vet Microbiol 62:35-45

Decostere A, Haesebrouck F, Turnbull JF, Charlier G (1999) Influence of water quality and temperature on adhesion of high and low virulence Flavobacterium columnare strains to isolated gill arches. J Fish Dis 22:1-11

Figueiredo HPC, Klesius PH, Arias CR, Evans J, Shoemaker CA, Pereira DJ Jr, Peixoto MTD (2005) Isolation and characterization of strains of Flavobacterium columnare from Brazil. J Fish Dis 28:199-204

Fisher MM, Triplett EW (1999) Automated approach for ribosomal intergenic spacer analysis of microbial diversity and its application to freshwater bacterial communities. Appl Environ Microbiol 65:4630-4636

Gandon S, Jansen VAA, van Baalen M (2001) Host life history and the evolution of parasite virulence. Evolution 55: 1056-1062

Gurtler V, Stanisich VA (1996) New approaches to typing and identification of bacteria using the 16S-23S rDNA spacer region. Microbiology 142:3-16

Koski P, Hirvelä-Koski V, Bernardet JF (1993) Flexibacter columnaris infection in arctic charr (Salvelinus alpinus L.): first isolation in Finland. Bull Eur Assoc Fish Pathol 13: 66-69

Leblond-Bourget N, Philippe H, Mangin I, Decaris B (1996) $16 \mathrm{~S}$ rRNA and $16 \mathrm{~S}$ to $23 \mathrm{~S}$ internal transcribed spacer sequence analyses reveal inter- and intraspecific Bifidobacterium phylogeny. Int J Syst Bacteriol 46:102-111

Madetoja J, Hänninen ML, Hirvelä-Koski V, Dalsgaard I, Wiklund T (2001) Phenotypic and genotypic characterization of Flavobacterium psychrophilum from Finnish fish farms. J Fish Dis 24:469-479

Michel C, Messiaen S, Bernardet JF (2002) Muscle infection in imported neon tetra, Paracheiodon innesi Myers: limited occurrence of microsporidia and predominance of severe forms of columnaris diseases caused by Asian genomovar of Flavobacterium columnare. J Fish Dis 25: 253-263

Muyzer G, De Waal EC, Uitterlinden AG (1993) Profiling complex microbial populations by denaturating gradient gel electrophoresis analysis of polymerase chain reactionamplified genes coding for 16S rRNA. Appl Environ Microbiol 2:2156-2162
Nakagawa Y, Sakane T, Suzuki M, Hatano K (2002) Phylogenetic structure of the genera Flexibacter, Flexithrix, and Microscilla deducted from 16S rRNa sequence analysis. J Appl Gen Microbiol 48:155-165

NCCLS (National Committee for Clinical Laboratory Standards) (1999) Performance standard for antimicrobial susceptibility testing. In: 9th international supplement, NCCLS document M100-S9. NCCLS, Wayne, PA

Read AF, Taylor LH (2001) The ecology of genetically diverse infections. Science 292:1099-1102

Revetta RP, Rodgers MR, Kinkle BK (2005) Isolation and identification of freshwater bacteria antagonistic to Giardia intestinalis cysts. J Water Health 3:83-88

Rickard AH, McBain AJ, Ledder RG, Handley PS, Gilbert P (2003) Coaggregation between freshwater bacteria within biofilm and planktonic communities. FEMS Microbiol Lett 220:133-140

Sambrook J, Fritsch EF, Maniatis T (1989) Molecular cloning: a laboratory manual. Cold Spring Harbor Laboratory Press, Cold Spring Harbor, NY

Schwieger F, Tebbe CC (1998) A new approach to utilize PCR-single-strand-conformation polymorphism for $16 \mathrm{~S}$ rDNA gene-based microbial community analysis. Appl Environ Microbiol 64:4870-4876

Shamsudin MN, Plumb JA (1996) Morphological, biochemical, and physiological characterization of Flexibacter columnaris isolates from four species of fish. J Aquat Anim Health 8:335-339

Song YL, Fryer JL, Rohovec JS (1988) Comparison of gliding bacteria isolated from fish in North America and other areas of the Pacific rim. Fish Pathol 23:197-202

Suomalainen LR (2005) Flavobacterium columnare in Finnish fish farming: characterisation and putative disease management strategies. Jyväskylä Stud Biol Environ Sci 155:1-52

Suomalainen LR, Tiirola M, Valtonen E (2005a) The influence of rearing conditions on Flavobacterium columnare infection of rainbow trout. J Fish Dis 28:271-277

Suomalainen LR, Tiirola M, Valtonen ET (2005b) Treatment of columnaris disease of rainbow trout: low $\mathrm{pH}$ and salt as possible tools? Dis Aquat Org 65:115-120

Suzuki M, Rappe MS, Giovannoni SJ (1998) Kinetic bias in estimates of coastal picoplankton community structure obtained by measurements of small-subunit rRNA gene PCR amplicon length heterogeneity. Appl Environ Microbiol 64:4522-4529

Thomas-Jinu S, Goodwin AE (2004) Morphological and genetic characteristics of Flavobacterium columnare isolates: correlations with virulence in fish. J Fish Dis 27: 29-35

Tiirola MA, Suvilampi JE, Kulomaa MS, Rintala JA (2003) Microbial diversity in a thermophilic aerobic biofilm process: analysis by length heterogeneity PCR (LH-PCR). Water Res 37:2259-2268

Toyama T, Kita-Tsukamoto K, Wakabayashi H (1996) Identification of Flexibacter maritimus, Flavobacterium branchiophilum and Cytophaga columnaris by PCR targeted 16S ribosomal DNA. Fish Pathol 31:25-31

Triyanto, Wakabayashi H (1999) Genotypic diversity of strains of Flavobacterium columnare from diseased fishes. Fish Pathol 34:65-71

Triyanto, Kumamaru A, Wakabayashi H (1999) The use of PCR targeted 16S rDNA for identification of genomovars of Flavobacterium columnare. Fish Pathol 34:217-218

Weisburg WG, Barns SM, Pelletier DA, Lane DJ (1991) 16S ribosomal DNA amplification for phylogenetic analysis. J Bacteriol 173:697-703

Submitted: June 9, 2005; Accepted: November 16, 2005

Proofs received from author(s): March 25, 2005 